\title{
Managing Adaptation Processes of the Enterprise Economic Security System to the Influence of the Customs Regulation Entities
}

\author{
Yevhenii Rudnichenko ${ }^{1}$, Serhii Matiukh ${ }^{1}$, Nataliia Shuprudko ${ }^{2}$, \\ Raisa Kvasnytska ${ }^{1}$, Inna Dotsenko ${ }^{1}$, Anatolii Yaroslavskyi ${ }^{3}$ \\ ${ }^{1}$ Khmelnitsky National University, Khmelnitsky, Ukraine \\ ${ }^{2}$ Chernivtsi Institute of Trade and Economics of Kyiv National University of Trade and Economics, \\ Chernivtsi, Ukraine \\ ${ }^{3}$ Vinnytsia National Agrarian University, Vinnytsia, Ukraine
}

\begin{abstract}
A monitoring chart of the enterprise economic security system adaptation to the influence of the customs regulation entities has been developed in the study. The monitoring chart of the enterprise economic security system adaptation to the influence of the customs regulation entities contains a set of indicators grouped into four relatively independent categories: internal processes, processes of the interaction with the customs regulation entities, staff and financial indicators of the interaction with the customs regulation entities. The content of each of the chart's indicators is considered and the corresponding scale proposed. The gradations with description of the specific content comprising each of them are described and the sources of information are specified. The main management tool for the enterprise economic security system adaptation to the influence of the customs regulation entities is proposed. The tool is an appropriate adaptation program. The adaptation program comprises the following individual parts: general, analytical, content, organizational, monitoring, regulatory and informational.
\end{abstract}

Keywords - economic security, economic security system, customs regulation entities, adaptation, adaptation monitoring chart, adaptation program.

DOI: 10.18421/TEM93-35

https://doi.org/10.18421/TEM93-35

Corresponding author: Yevhenii Rudnichenko,

Khmelnitsky National University, Khmelnitsky, Ukraine.

Email: e.m.rudnichenko@gmail.com

Received: 18 March 2020.

Revised: 19 June 2020.

Accepted: 28 June 2020.

Published: 28 August 2020.

(cc) BY-NC-ND (C) 2020 Yevhenii Rudnichenko et al; published by UIKTEN. This work is licensed under the Creative Commons Attribution-NonCommercial-NoDerivs 4.0 License.

The article is published with Open Access at www.temjournal.com

\section{Introduction}

The influence of the customs regulation entities on the economic security system of Ukrainian enterprises is significant, although its effectiveness is doubtful on the part of both the enterprises and the state. Excessive fiscal authorities' pressure on the enterprises enables the creation of the shadow economy and opportunistic behavior of state agents. Consequently, this leads to a shortfall of the investment attractiveness within domestic economy and a decrease in state budget revenues. The business environment responds to these facts by withdrawing capital and developing tax optimization (minimization) schemes. In fact, in this situation, allelopathy is observed: due to the excessive fiscal and regulatory influence, both sides of economic relations - enterprises and the state - lose money as the enterprises gradually, either enter the shadow economy or reduce their activities until termination or redevelopment [4], [8]. Empirically, such allelopathy is confirmed by the Laffer curve [7], which illustrates the dependence of the amount of collected taxes on the tax rate. The validity of such allelopathy for the interaction of customs and business entities is undoubted. Taking into consideration the fact that the enterprises currently do not have effective mechanisms to influence the controlling bodies, due to their lack of publicity and willingness to dialogue with the business environment, the most appropriate behavior is to adapt to the existing environmental conditions [1], [12]. This requires an appropriate program of steps including adjusting the influence of customs entities. It should be noted that, unfortunately, individual enterprises and even sectorial or territorial associations of enterprises cannot influence the activity of the customs regulation entities. They are forced to work in the legal field and in accordance with the existing mode of interaction with the customs regulation entities.

In general, the problems of the state of economic security at the macro, meso and micro levels are 
considered in the works of domestic and foreign researchers. Among them are: Havlovska N.I. [3] who examines the economic security of foreign economic activity. The peculiarity of these studies is a detailed consideration of the specifics of globalization processes at the macro level and their direct impact on the economic security of foreign economic activity at the micro level. Vasyltsiv T.H. [11], who in his research emphasized the importance of the influence of state institutions on the economic security of the macro, meso and micro levels. At the same time, he is focusing on improving the regulatory framework and improving the work of regulatory authorities. Kozachenko H.V., Pohorelov Yu.S. [5], [6] who in their fundamental studies of economic security at the macro and micro levels, explain the nature of the behavior of institutional agents and individual enterprises from the standpoint of evolutionary theory and the postulates of classical management. Rudnichenko Ye.M. [9], who explains the behavior of institutional agents and business entities from the standpoint of institutional theory and focuses on the provisions of evolutionary economics, which explains the peculiarities of the interaction involving different actors in the transformation processes of the macro level.

Issues in regard to formation of customs security and active interaction of subjects of customs regulation and business entities, reflected in the works [2], [10] where harmonization approaches to the interaction of state institutions and subjects of foreign economic activity are proposed, which as a result leads to a positive economic effect, both at the macro and micro levels. Although, the issues of adaptation and agile management are practically not considered by the above authors and solving problems of economic security require further research.

Taking into consideration the scientific value and practical importance of the above mentioned studies, it should be noted that a number of conceptual and methodological issues have not been studied thoroughly. The problem of the enterprise economic security formation with the influence of the fiscal authorities has not been investigated enough.

\section{Research Method}

In order to ensure the successful functioning of the enterprise in the conditions of changing influence regarding the customs regulation entities, the adaptation of the economic security system should take place. As a result, the economic security system has to obtain new content, elements, and become adapted to the new influence of the customs regulation entities. Eventually, the adaptation of the economic security system should become the basis for adaptation of the enterprise as a whole. In order to adapt the enterprise economic security system to the influence of the customs regulation entities, it is necessary to develop a specialized analysis tools for an appropriate monitoring of the adaptation of the enterprise economic security system to the influence of the customs regulation entities. Consequently, this instrument will be referred to as "a monitoring chart of the enterprise economic security system adaptation to the influence of the customs regulation entities". In the process of developing the monitoring chart of the enterprise economic security system adaptation to the influence of the customs regulation entities of primary importance and relevance are the groups of indicators that characterize the process of adaptation of the economic security system to the influence of the customs regulation entities. Another important factor is the combinability of individual indicators with the parameters of adaptation and the trial dependence «catalysts/inhibitors including influence-parameters of adaptation-indicators of the adaptation process». Table 1 presents the list of indicators in the monitoring chart of the enterprise economic security system adaptation to the influence of the customs regulation entities.

The list (Table 1) can be used both for assessing the influence of customs entities on the enterprise (restricted application), and for direct monitoring of the enterprise economic security system adaptation to the influence of the customs regulation entities.

To interpret the obtained meanings of the listed indicators respecting the monitoring chart of the enterprise economic security system adaptation to the influence of the customs regulation entities it is necessary to know the limits of such gradations.

For this purpose, the limits for each term of qualitative interpretation of the proposed indicators are presented in Table 2.

It should be noted that for some indicators the binary estimation characterizes the fact of the presence or absence of an element, but for more detailed qualitative analysis the partial implementation of some elements should be taken into consideration.

In addition, it should be mentioned that it is quite difficult and almost impossible to perform calculation using the algorithmic methods, due to the absence of a universal measuring instrument and uniqueness in the gradation of the given indicators. It is logical in this case to apply linear profiles for individual groups of indicators in order to substantiate the researched processes. This complication is justified by the relevance of the studied issue for economic entities. There are no universal methods due to the novelty of the suggested approach in the context of interaction with customs regulation entities.

Consequently, for practical use, all indicators in the monitoring chart of the enterprise economic security system adaptation to the influence of the customs regulation entities should be determined. This requires the use of certain primary information, which has to be taken from specific sources. 
Table 1. Groups of indicators in the monitoring chart of the enterprise economic security system adaptation to the influence of the customs regulation entities

\begin{tabular}{|c|c|c|}
\hline Group of Indicators & Indicators & Scale \\
\hline \multirow{5}{*}{ Internal Processes } & $\begin{array}{l}\text { Availability of specific adaptation measures implemented in the overall enterprise management } \\
\text { system }\end{array}$ & Binary (yes/no) \\
\hline & Reliability of customs risk management procedures & Binary (yes/no) \\
\hline & Existence of internal customs audit system & Binary (yes/no) \\
\hline & Filing in electronic declarations & Binary (yes/no) \\
\hline & Average time for customs clearance of one consignment (hours) & Quantitative interval \\
\hline \multirow{5}{*}{$\begin{array}{l}\text { Processes of the } \\
\text { interaction with the } \\
\text { customs regulation } \\
\text { entities }\end{array}$} & Protocols of violation of customs rules over the last 3 years & Quantitative interval \\
\hline & Dynamics of the number of customs rules violation protocols over the last 3 years & $\begin{array}{l}\text { Trinary (positive, } \\
\text { neutral, negative) }\end{array}$ \\
\hline & Number of enterprises inspections by the customs regulation entities & Quantitative interval \\
\hline & $\begin{array}{l}\text { Dynamics of the number of enterprise inspections by the customs regulation entities over the } \\
\text { last } 3 \text { years }\end{array}$ & $\begin{array}{l}\text { Trinary (positive, } \\
\text { neutral, negative) }\end{array}$ \\
\hline & The average time of the accreditation (days) by the customs regulation authorities & Quantitative interval \\
\hline \multirow{3}{*}{ Staff } & Staffing level of the Economic Security Department, \% & Quantitative interval \\
\hline & Number of specialists involved in cooperation with the customs regulation entities & Quantitative interval \\
\hline & $\begin{array}{l}\text { Relation of motivation of the employees of the Economic Security Department with the results } \\
\text { of adaptation }\end{array}$ & Binary (yes/no) \\
\hline \multirow{4}{*}{$\begin{array}{l}\text { Financial indicators } \\
\text { of interaction with } \\
\text { the customs } \\
\text { regulation entities }\end{array}$} & Transaction costs percentage of implementing the law & Quantitative interval \\
\hline & The share of income spent on forming relations with the customs regulation entities & Quantitative interval \\
\hline & $\begin{array}{l}\text { The fact of imposing financial sanctions on an enterprise for non-compliance with customs } \\
\text { legislation }\end{array}$ & Binary (yes/no) \\
\hline & Facts of adjustment of the declared market value of the goods & Binary (yes/no) \\
\hline
\end{tabular}

Table 2. Qualitative interpretation of gradations indicators as part of the monitoring chart of the enterprise economic security system adaptation to the influence of the customs regulation entities

\begin{tabular}{|c|c|c|c|c|c|}
\hline \multirow{2}{*}{ Indicator } & \multicolumn{5}{|c|}{ Gradations } \\
\hline & Unsatisfactory & Below average & Satisfactory & Good & Excellent \\
\hline $\begin{array}{l}\text { Availability of specific } \\
\text { adaptation measures } \\
\text { implemented in the overall } \\
\text { enterprise management system }\end{array}$ & $\begin{array}{l}\text { Adaptation } \\
\text { measures are } \\
\text { absent }\end{array}$ & $\begin{array}{l}\text { There are only plans } \\
\text { to implement } \\
\text { specific adaptation } \\
\text { measures to the } \\
\text { influence of customs } \\
\text { regulation entities }\end{array}$ & $\begin{array}{l}\text { Some specific } \\
\text { adaptation measures } \\
\text { to the influence of } \\
\text { customs regulation } \\
\text { entities are partially } \\
\text { implemented }\end{array}$ & $\begin{array}{l}\text { A set of specific } \\
\text { adaptation } \\
\text { measures to the } \\
\text { influence of } \\
\text { customs regulation } \\
\text { entities is } \\
\text { implemented }\end{array}$ & $\begin{array}{l}\text { A complex of specific } \\
\text { adaptation measures to } \\
\text { the influence of } \\
\text { customs regulation } \\
\text { entities is successfully } \\
\text { implemented }\end{array}$ \\
\hline $\begin{array}{l}\text { Reliability of customs risk } \\
\text { management procedures }\end{array}$ & $\begin{array}{c}\text { Customs risk } \\
\text { management } \\
\text { procedures are } \\
\text { absent }\end{array}$ & $\begin{array}{l}\text { Some customs risk } \\
\text { management } \\
\text { procedures are } \\
\text { implemented }\end{array}$ & $\begin{array}{l}\text { Separate customs risk } \\
\text { management } \\
\text { procedures are } \\
\text { partially implemented }\end{array}$ & $\begin{array}{l}\text { A set of customs } \\
\text { risk management } \\
\text { procedures is } \\
\text { implemented }\end{array}$ & $\begin{array}{l}\text { A complex of } \\
\text { coordinated customs } \\
\text { risk management } \\
\text { procedures is } \\
\text { successfully } \\
\text { implemented }\end{array}$ \\
\hline $\begin{array}{l}\text { Existence of internal customs } \\
\text { audit system }\end{array}$ & $\begin{array}{c}\text { Internal customs } \\
\text { audit procedures } \\
\text { are absent }\end{array}$ & $\begin{array}{c}\text { Some internal } \\
\text { customs audit } \\
\text { procedures are } \\
\text { implemented }\end{array}$ & $\begin{array}{c}\text { Separate internal } \\
\text { customs audit } \\
\text { procedures are } \\
\text { partially implemented }\end{array}$ & $\begin{array}{l}\text { A set of internal } \\
\text { customs audit } \\
\text { procedures is } \\
\text { implemented }\end{array}$ & $\begin{array}{l}\text { Internal customs audit } \\
\text { system is implemented }\end{array}$ \\
\hline $\begin{array}{l}\text { Filing in electronic declarations } \\
\text { (yes/no) }\end{array}$ & $\begin{array}{l}\text { The possibility } \\
\text { of filing in } \\
\text { electronic } \\
\text { declaration was } \\
\text { not considered }\end{array}$ & $\begin{array}{l}\text { The possibility of } \\
\text { filing in electronic } \\
\text { declaration is } \\
\text { considered }\end{array}$ & $\begin{array}{c}\text { Electronic } \\
\text { declarations are filled } \\
\text { in occasionally }\end{array}$ & $\begin{array}{c}\text { Electronic } \\
\text { declarations are } \\
\text { filled in from time } \\
\text { to time }\end{array}$ & $\begin{array}{l}\text { Electronic declarations } \\
\text { are filled in } \\
\text { permanently }\end{array}$ \\
\hline $\begin{array}{l}\text { Average time for customs } \\
\text { clearance of one consignment }\end{array}$ & 8 and more & 6 & 4 & 2 & $<1$ \\
\hline $\begin{array}{l}\text { Protocols of violation of } \\
\text { customs rules over the last } 3 \\
\text { years }\end{array}$ & 4 and more & 3 & 2 & 1 & 0 \\
\hline $\begin{array}{l}\text { Dynamics of the number of } \\
\text { customs rules violation } \\
\text { protocols over the last } 3 \text { years }\end{array}$ & positive & - & neutral & - & negative \\
\hline $\begin{array}{l}\text { Number of enterprises } \\
\text { inspections by the customs } \\
\text { regulation entities }\end{array}$ & 4 & 3 & 2 & 1 & 0 \\
\hline $\begin{array}{l}\text { Dynamics of the number of } \\
\text { enterprises inspections by the } \\
\text { customs regulation entities over } \\
\text { the last } 3 \text { years }\end{array}$ & positive & - & neutral & - & negative \\
\hline
\end{tabular}




\begin{tabular}{|c|c|c|c|c|c|}
\hline $\begin{array}{l}\text { The average time of the } \\
\text { accreditation (days) by the } \\
\text { customs regulation authorities }\end{array}$ & 21 and more & 14 & 7 & 3 & 1 \\
\hline $\begin{array}{l}\text { Number of specialists involved } \\
\text { in cooperation with the } \\
\text { customs regulation entities }\end{array}$ & 5 & 4 & 3 & 2 & 1 \\
\hline $\begin{array}{l}\text { Relation of motivation of the } \\
\text { employees of the Economic } \\
\text { Security Department with the } \\
\text { results of adaptation }\end{array}$ & $\begin{array}{l}\text { The relation is } \\
\text { absent }\end{array}$ & $\begin{array}{c}\text { Some elements of } \\
\text { motivation are } \\
\text { observed }\end{array}$ & $\begin{array}{l}\text { The motivation } \\
\text { measures are applied } \\
\text { occasionally }\end{array}$ & $\begin{array}{l}\text { Ehe motivation } \\
\text { measures are } \\
\text { applied regularly }\end{array}$ & $\begin{array}{l}\text { The complex } \\
\text { motivation program is } \\
\text { implemented }\end{array}$ \\
\hline $\begin{array}{l}\text { Percentage of transaction costs } \\
\text { for implementing the law }\end{array}$ & 10 and more & 5 & 3 & 1 & 0 \\
\hline $\begin{array}{l}\text { The share of income spent on } \\
\text { forming relations with the } \\
\text { customs regulation entities }\end{array}$ & 5 & 4 & 3 & 2 & 1 \\
\hline $\begin{array}{l}\text { The fact of imposing financial } \\
\text { sanctions on the enterprise for } \\
\text { non-compliance with customs } \\
\text { legislation }\end{array}$ & $\begin{array}{l}\text { on a regular } \\
\text { basis }\end{array}$ & incidental & seldom & random & never \\
\hline $\begin{array}{l}\text { Facts of adjustment of the } \\
\text { declared market value of the } \\
\text { goods }\end{array}$ & $\begin{array}{l}\text { on a regular } \\
\text { basis }\end{array}$ & incidental & seldom & random & never \\
\hline $\begin{array}{l}\text { Staffing level of the Economic } \\
\text { Security Department, \% }\end{array}$ & 20 and less & 40 & 60 & 80 & 100 \\
\hline
\end{tabular}

Therefore, the sources of information for each influence of the customs regulation entities are indicator suggested in monitoring chart of the represented in Table 3.

enterprise economic security system adaptation to the

Table 3. The sources of information for indicators suggested in monitoring chart of the enterprise economic security system adaptation to the influence of the customs regulation entities

\begin{tabular}{|c|c|c|c|c|c|}
\hline \multirow[b]{2}{*}{ Indicator } & \multicolumn{5}{|c|}{ Sources of Information } \\
\hline & 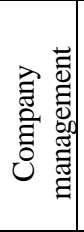 & 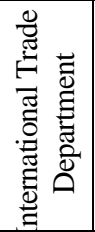 & 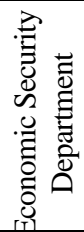 & 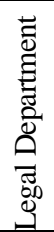 & 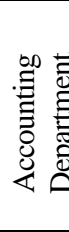 \\
\hline Availability of specific adaptation measures implemented in the overall enterprise management system & $\mathrm{X}$ & & & & \\
\hline Reliability of customs risk management procedures & $\mathrm{X}$ & $\mathrm{X}$ & $\mathrm{X}$ & & \\
\hline Existence of internal customs audit system & $\mathrm{X}$ & $\mathrm{X}$ & $\mathrm{X}$ & & $\mathrm{X}$ \\
\hline Filing in electronic declarations & & $\mathrm{X}$ & & & $\mathrm{X}$ \\
\hline Average time for customs clearance of one consignment (hours) & & $\mathrm{X}$ & & & \\
\hline Protocols of violation of customs rules over the last 3 years & & $\mathrm{X}$ & & $\mathrm{X}$ & \\
\hline Dynamics of the number of customs rules violation protocols over the last 3 years & & $\mathrm{X}$ & & $\mathrm{X}$ & \\
\hline Number of enterprises inspections by the customs regulation entities & & $\mathrm{X}$ & $\mathrm{X}$ & & $\mathrm{X}$ \\
\hline $\begin{array}{l}\text { Dynamics of the number of enterprises inspections by the customs regulation entities over the last } \\
3 \text { years }\end{array}$ & & $\mathrm{X}$ & $X$ & & \\
\hline The average time of the accreditation (days) by the customs regulation authorities & & $\mathrm{X}$ & & $\mathrm{X}$ & \\
\hline Staffing level of the Economic Security Department, \% & $\mathrm{X}$ & & $\mathrm{X}$ & & \\
\hline Number of specialists involved in cooperation with the customs regulation entities & $\mathrm{X}$ & & $\mathrm{X}$ & & \\
\hline $\begin{array}{l}\text { Relation of motivation of the employees of the Economic Security Department with the results of } \\
\text { adaptation }\end{array}$ & $\mathrm{X}$ & & $\mathrm{X}$ & & $\mathrm{X}$ \\
\hline Transaction costs percentage of implementing the law & & & $\mathrm{X}$ & & \\
\hline The share of income spent on forming relations with the customs regulation entities & & & $\mathrm{X}$ & & \\
\hline The fact of imposing financial sanctions on an enterprise for non-compliance with customs legislation & & & $\mathrm{X}$ & & $\mathrm{X}$ \\
\hline Facts of adjustment of the declared market value of the goods & & $\mathrm{X}$ & $\mathrm{X}$ & & $\mathrm{X}$ \\
\hline
\end{tabular}

It should be emphasized that the quality of information depends on its sources. According to the data presented in Table 3, the key role in obtaining information belongs to the Enterprise International Trade Departments and Economic Security Departments.

\section{Results}

For the practical approval, the small private enterprise «Skhid» was selected. The private enterprise «Skhid» is an innovation-active international trade entity, which has been among the top twenty enterprises in the Ukraine footwear 
industry according to the ratings of Ukraine light industry. According to the monitoring chart of the private enterprise «Skhid» economic security system adaptation to the influence of the customs regulation entities in 2018 (Table 4), it is necessary to acknowledge the absence of specific adaptation measures implemented in the overall enterprise management system.

Table 4. The monitoring chart of the «Skhid» private enterprise economic security system adaptation to the influence of the customs regulation entities, 2018

\begin{tabular}{|c|c|c|}
\hline Indicator & Meaning & $\begin{array}{l}\text { Gradation } \\
\text { (see Table 3) }\end{array}$ \\
\hline \multicolumn{3}{|l|}{2018} \\
\hline $\begin{array}{l}\text { Availability of specific adaptation measures implemented in the overall } \\
\text { enterprise management system }\end{array}$ & Adaptation measures are absent & Unsatisfactory \\
\hline Reliability of customs risk management procedures & Customs risk management procedures are absent & Unsatisfactory \\
\hline Existence of internal customs audit system & Internal customs audit procedures are absent & Unsatisfactory \\
\hline Filing in electronic declarations & $\begin{array}{l}\text { The possibility of filing in electronic } \\
\text { declaration was not considered }\end{array}$ & Unsatisfactory \\
\hline Average time for customs clearance of one consignment (hours) & 4 & Satisfactory \\
\hline Protocols of violation of customs rules over the last 3 years & 1 & Good \\
\hline $\begin{array}{l}\text { Dynamics of the number of customs rules violation protocols over the } \\
\text { last } 3 \text { years }\end{array}$ & Neutral & Satisfactory \\
\hline Number of enterprises inspections by the customs regulation entities & 1 & Good \\
\hline $\begin{array}{l}\text { Dynamics of the number of enterprises inspections by the customs } \\
\text { regulation entities over the last } 3 \text { years }\end{array}$ & Neutral & Good \\
\hline $\begin{array}{l}\text { The average time of the accreditation (days) by the customs regulation } \\
\text { authorities }\end{array}$ & 14 & Below average \\
\hline Staffing level of the Economic Security Department, \% & 20 and less & Unsatisfactory \\
\hline $\begin{array}{l}\text { Number of specialists involved in cooperation with the customs } \\
\text { regulation entities }\end{array}$ & 2 & Good \\
\hline $\begin{array}{l}\text { Relation of motivation of the employees of the Economic Security } \\
\text { Department with the results of adaptation }\end{array}$ & The relation is absent & Unsatisfactory \\
\hline Transaction costs percentage of implementing the law & 5 & Below average \\
\hline $\begin{array}{l}\text { The share of income spent on forming relations with the customs } \\
\text { regulation entities }\end{array}$ & 3 & Satisfactory \\
\hline $\begin{array}{l}\text { The fact of imposing financial sanctions on an enterprise for non- } \\
\text { compliance with customs legislation }\end{array}$ & Random & Good \\
\hline Facts of adjustment of the declared market value of the goods & Random & Good \\
\hline \multicolumn{3}{|l|}{2019} \\
\hline $\begin{array}{l}\text { Availability of specific adaptation measures implemented in the overall } \\
\text { enterprise management system }\end{array}$ & $\begin{array}{l}\text { Separate specific adaptation measures to the } \\
\text { influence of customs regulation entities are } \\
\text { partially implemented }\end{array}$ & Satisfactory \\
\hline Reliability of customs risk management procedures & $\begin{array}{c}\begin{array}{c}\text { Some customs risk management procedures are } \\
\text { implemented }\end{array} \\
\end{array}$ & Below average \\
\hline Existence of internal customs audit system & $\begin{array}{c}\begin{array}{c}\text { Some internal customs audit procedures are } \\
\text { partially implemented }\end{array} \\
\end{array}$ & Satisfactory \\
\hline Filing in electronic declarations & $\begin{array}{l}\text { The possibility of filing in electronic } \\
\text { declaration is considered }\end{array}$ & Below average \\
\hline Average time for customs clearance of one consignment (hours) & 4 & Satisfactory \\
\hline Protocols of violation of customs rules over the last 3 years & 1 & Good \\
\hline $\begin{array}{l}\text { Dynamics of the number of customs rules violation protocols over the } \\
\text { last } 3 \text { years }\end{array}$ & Neutral & Satisfactory \\
\hline Number of enterprises inspections by the customs regulation entities & 1 & Good \\
\hline $\begin{array}{l}\text { Dynamics of the number of enterprises inspections by the customs } \\
\text { regulation entities over the last } 3 \text { years }\end{array}$ & Neutral & Good \\
\hline $\begin{array}{l}\text { The average time of the accreditation (days) by the customs regulation } \\
\text { authorities }\end{array}$ & 7 & Satisfactory \\
\hline Staffing level of the Economic Security Department, \% & 40 & Below average \\
\hline $\begin{array}{l}\text { Number of specialists involved in cooperation with the customs } \\
\text { regulation entities }\end{array}$ & 2 & Good \\
\hline $\begin{array}{l}\text { Relation of motivation of the employees of the Economic Security } \\
\text { Department with the results of adaptation }\end{array}$ & Some elements of motivation are observed & Below average \\
\hline Transaction costs percentage of implementing the law & 3 & Satisfactory \\
\hline $\begin{array}{l}\text { The share of income spent on forming relations with the customs } \\
\text { regulation entities }\end{array}$ & 2 & Good \\
\hline $\begin{array}{l}\text { The fact of imposing financial sanctions on an enterprise for non- } \\
\text { compliance with customs legislation }\end{array}$ & Incidental & $\begin{array}{c}\text { There are no } \\
\text { such facts }\end{array}$ \\
\hline Facts of adjustment of the declared market value of the goods & Incidental & $\begin{array}{c}\text { There are no } \\
\text { such facts }\end{array}$ \\
\hline
\end{tabular}


The enterprise occasionally interacts with the customs regulation entities, because one of the strategic directions of its work is expansion of markets and increase of export volume. It should be noted that it constantly imports raw materials from Poland and Italy. Adaptation of the private enterprise «Skhid» to the influence of the customs regulation entities should take place in accordance with the strategic goals of enterprise development. According to the facts, the economic security system at the enterprise is fragmented. The employees are not motivated to find alternative ways of interaction with the customs regulation entities. There are recurrent violations of customs rules and adjustment of the customs value of goods. The transaction costs percentage of implementing the law is $5 \%$ and $3 \%$ of the revenue share. This money is spent on forming relations with the customs regulation entities and the sums are quite significant. Therefore, in 2019, in accordance with our recommendations, the private enterprise «Skhid» began to focus on improving relations with the customs regulation entities, which had a positive impact on adaptation processes (Table 4).

It is obvious that the adaptation processes cannot take place immediately. In this case some inertia regarding regulation of such processes at the state level and the imperfection of the tools of interaction between the customs regulation entities and enterprises have to be taken into account.

However, emphasizing management's attention to these issues, as well as expanding the authority (or even creating) of the Enterprise Economic Security Department, allows improving the process of interaction of these entities promptly (Figure 1).

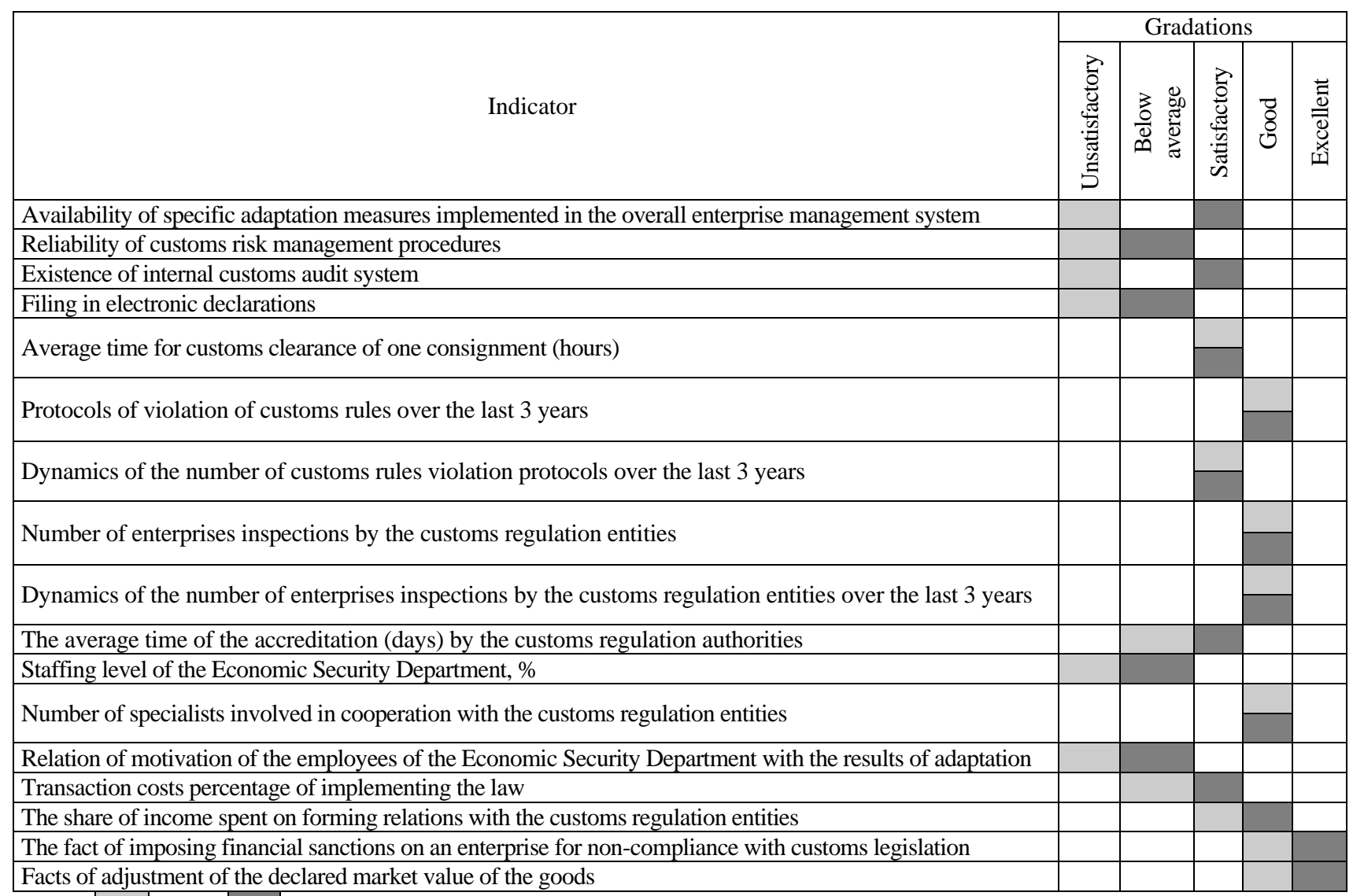

Figure 1. The linear profiles of the «Skhid» private enterprise economic security system adaptation to the influence of the customs regulation entities in 2018-2019

This is clearly illustrated in Figure 1, which presents the linear profiles of the «Skhid» private enterprise economic security system adaptation to the influence of the customs regulation entities in 20182019.

The indicated profiles prove positive changes, improving the interaction between customs and economic entities. Although a rapid increase in the volume of foreign economic activity of enterprises should not be expected immediately.

In order to implement the proposals and recommendations suggested in the study regarding the enterprise economic security system adaptation to the influence of the customs regulation entities, it is necessary to offer a clear strategy, which will be adequately perceived not only by the top management of the enterprises, but also by executors. It should be emphasized that the private enterprise «Skhid» belongs to the enterprises of light industry and produces footwear. Sales volumes depend mainly on the enterprise foreign economic activity.

The distinctive aspect of the enterprise activity is the import of raw materials for production and export of finished goods (Table 5). 
Table 5. The anti-crisis program of the «Skhid» private enterprise economic security system adaptation to the influence of the customs regulation entities

\begin{tabular}{|c|c|}
\hline Elements & Profile \\
\hline \multicolumn{2}{|r|}{ General Component } \\
\hline Introduction & $\begin{array}{l}\text { Creation of the enterprise's effective economic security system taking into consideration the } \\
\text { peculiarities of foreign trade and adaptation processes at the enterprise level }\end{array}$ \\
\hline Aim & $\begin{array}{l}\text { Reducing the occurrence of crisis developments at the enterprise by minimizing the negative impact of } \\
\text { the customs regulation entities and intensification of foreign economic activity }\end{array}$ \\
\hline Task & $\begin{array}{l}\text { Initiation and activation of the enterprise economic security system of adaptation processes to the } \\
\text { influence of the customs regulation entities }\end{array}$ \\
\hline \multicolumn{2}{|r|}{ Analytical Component } \\
\hline $\begin{array}{l}\text { Analysis of the customs } \\
\text { regulation entities' influence } \\
\text { on the enterprise }\end{array}$ & $\begin{array}{l}\text { Identification of the main problems and the need for adaptive changes in the enterprise economic } \\
\text { security }\end{array}$ \\
\hline $\begin{array}{l}\text { Analysis of the influence } \\
\text { factors }\end{array}$ & $\begin{array}{l}\text { Analysis of the enterprise foreign economic activity, the possibility and dynamics of the customs rules } \\
\text { violations, the conflict situations in the customs clearance of goods and ways of solving them, the facts } \\
\text { of opportunistic behavior of representatives of the customs regulation entities }\end{array}$ \\
\hline Interaction analysis & $\begin{array}{l}\text { Designation of the degree of crisis in the relationship between the enterprise and the customs regulation } \\
\text { entities }\end{array}$ \\
\hline \multicolumn{2}{|r|}{ Content Component } \\
\hline $\begin{array}{l}\text { Internal customs audit system } \\
\text { implementation }\end{array}$ & $\begin{array}{l}\text { Development of an ordinance on the internal customs audit system, identifying responsible parties and } \\
\text { main users of the resulting information }\end{array}$ \\
\hline $\begin{array}{l}\text { Filing in electronic } \\
\text { declarations }\end{array}$ & Effective implementation of electronic declaration \\
\hline $\begin{array}{l}\text { Reducing the number of audits } \\
\text { and facilitating the } \\
\text { implementation of electronic } \\
\text { audits }\end{array}$ & A number of measures to promote the implementation of electronic audits \\
\hline $\begin{array}{l}\text { Reducing the level of } \\
\text { transaction and «protective» } \\
\text { costs }\end{array}$ & $\begin{array}{l}\text { Reconsidering and optimization of the key expenditures, especially regarding customs regulation } \\
\text { entities }\end{array}$ \\
\hline \multicolumn{2}{|r|}{ Regulation and Information Component } \\
\hline Regulation control & $\begin{array}{l}\text { Prompt development of regulations, instructions and programs regulating the adaptation of the } \\
\text { enterprise economic security system to the influence of the customs regulation entities }\end{array}$ \\
\hline Information support & $\begin{array}{l}\text { Identification of the main sources of information, as well as the regulation of procedures for the } \\
\text { collection, processing and modification of the internal reports about foreign economic activity }\end{array}$ \\
\hline \multicolumn{2}{|r|}{ Organizational Component } \\
\hline Organizational assistance & $\begin{array}{l}\text { Regulating the activity of the Enterprise Economic Security Department and determining the officially } \\
\text { responsible workers who directly monitor the enterprise adaptation changes and report about them to } \\
\text { executive management }\end{array}$ \\
\hline Human resourcing & Determination of the responsible workers' subordination and regulation of interaction procedures \\
\hline \multicolumn{2}{|r|}{ Monitoring Component } \\
\hline $\begin{array}{l}\text { Analysis of reports and their } \\
\text { evaluation }\end{array}$ & $\begin{array}{l}\text { Identification of the frequency of reports generation and their evaluation with appropriate adjustments to } \\
\text { the adaptation program }\end{array}$ \\
\hline Tools & Using a modified balanced scorecard \\
\hline
\end{tabular}

\section{Conclusions}

According to the results of practical approval including a monitoring chart of the enterprise economic security system adaptation to the influence of the customs regulation entities (evidence from an individual enterprise) and the study of the adaptation, it became possible to draw the following conclusions:

1) Regarding the quality of the developed monitoring chart of the enterprise economic security system adaptation to the influence of the customs regulation entities, its perplexity for perception by employees and management, as well as the availability of information for filling the content component should be emphasized;

2) The use of the developed monitoring chart of the «Skhid» private enterprise economic security system adaptation made it possible to identify the key problems of interaction with the customs regulation entities and to propose certain measures for the adaptation of the enterprise economic security system to their influence. The positive consequences comprise the activation of the adaptation processes, which is reflected in the changes of the linear profiles characterizing the positive dynamics of adaptation processes;

3) The defined and practically approved proposals for the development and implementation of the anti-crisis program of the «Skhid» private enterprise economic security system adaptation to the influence of the customs regulation entities have proved to be useful and effective for the foreign economic activity participants. Although the overall adaptation program is universal, the content of individual programs differs 
significantly in the scope of the proposed changes, the resources needed to implement them and the flow of implementation in each individual enterprise.

\section{References}

[1]. Brustbauer, J. (2016). Enterprise risk management in SMEs: Towards a structural model. International Small Business Journal, 34(1), 70-85.

[2]. Foley, R., \& Northway, B. (2010). Managing risk in customs: lessons from the New Zealand customs service. Investment climate in practice. $12,1-8$.

[3]. Havlovska N., Pokotylova V., Korpan O., Rudnichenko Ye., Sokyrnyk I. (2019). Modeling of the process of functioning of the mechanism of economic security of foreign economic activity of enterprise taking into account weak signals and identification of risks and threats. International Journal of Scientific \& Technology Research. 8(12), 2216-2522.

[4]. Horváthová, J., \& Mokrišová, M. (2018). Risk of bankruptcy, its determinants and models. Risks, 6(4), $1-22$.

[5]. Kozachenko, G. V., Pogorelov, Yu. S., Bilousova, A. Yu. (2019). Development of threats to enterprise activity. Security of the XXI century: national and geopolitical aspects: collective monograph. Prague Czech Repulic, 134-140. [In Ukrainian].
[6]. Kozačenko, G. V., \& Zavora, T. M. (2019). Ocinjuvannja social'no-ekonomičnoï bezpeki Poltavs'koï oblasti. Biznes Inform, (4 (495)).

[7]. Laffer, A. B. (2004). The Laffer curve: Past, present, and future. Backgrounder, 1765, 1-16.

[8]. Polozova, T., Cherkashina, M., Shapoval, O., Romanchik, T., \& Alzoubi, L. A. K. M. (2019). Assessment of risks in conditions of provision of security of economic activities of organizations. Journal of Security and Sustainability, Issues, 8(4), 705-714.

[9]. Rudnichenko, Y., Krymchak, L., Kudelskyi, V., Avanesova, N., Sokyrnyk, I., \& Havlovska, N. (2020). Minimization of Risks of the Enterprise Foreign Economic Activity through Improving the Interaction Management Quality with Potential Partners. Calitatea, 21(174), 61-67.

[10]. The creation of a Customs post-audit control system in Ukraine: monograph (2014); za zag. red. O.M. Vakul'chik. Khmelnitsky: PP Mel'nik A.A.

[11]. Vasyltsiv, T., \& Grynkevych, S. (2015). Environment for economic security of entrepreneurship formation in Ukraine. Economic Annals-XXI.

[12]. Yu, H., Yun, L., Ying, Z., Zhu, Z., \& Pingfeng, Z. (2014). Research on ranking evaluation models of safety risk in productive enterprises based on the perspective of supervision. Procedia Engineering, 84, 100-107. 